\title{
Pygocephalomorphan crustaceans further emphasise the similarities between the Carboniferous Piesberg quarry in Germany and the Mazon Creek Lagerstätte in North America
}

\author{
Paula Giovana Pazinato, Carolin Haug, \\ Angelika Leipner, and Joachim T. Haug
}

\begin{abstract}
The Upper Carboniferous Piesberg quarry close to Osnabrück, in Lower Saxony, Germany, has provided a high number of exceptionally preserved fossils of Euarthropoda. This includes "horseshoe crabs" (Xiphosurida), scorpions (Scorpionida), and other now extinct forms of Euchelicerata, namely spider-like species of Trigonotarbida, remains of true spiders (Arthrolycosa) and Phalangiotarbida. Furthermore, representatives of Insecta have also been recorded. Here we report on the remains of a pygocephalomorphan crustacean, a representative of an extinct, possibly nonmonophyletic, ingroup of Eumalacostraca. The comparison to other pygocephalomorphan fossils from the literature suggests that it is a record of Anthracaris gracilis, a species previously reported from the Pennsylvanian Konservat-Lagerstätten of Mazon Creek, Moscovian of the U.S.A., and Bickershaw, Bashkirian-Moscovian of England. The frequency and geographical distribution of eumalacostracan records from several Carboniferous deposits of North America, the UK, and continental Europe shows that Hoplocarida is the predominant group throughout the Carboniferous faunas, followed by Pygocephalomorpha in the Mississippian and Syncarida in the Pennsylvanian. Anthracaris gracilis is not the only faunal overlap between the Piesberg quarry, Mazon Creek, and the Bickershaw Lagerstätte; other such similarities are briefly listed and further emphasize a "faunal continuum" that persisted during the early Pennsylvanian across the deltaic depositional environments of North America, the UK, and continental Europe.
\end{abstract}

Paula Giovana Pazinato. LMU Munich, Faculty of Biology, Grosshaderner Str. 2, 82152 PlaneggMartinsried, Germany. paula.pazinato@palaeo-evo-devo.info

Carolin Haug. LMU Munich, Faculty of Biology, Grosshaderner Str. 2, 82152 Planegg-Martinsried, Germany, and LMU Munich, GeoBio-Center, Richard-Wagner-Str. 10, 80333 München, Germany.

\footnotetext{
Pazinato, Paula Giovana, Haug, Carolin, Leipner, Angelika, and Haug, Joachim T. 2022. Pygocephalomorphan crustaceans further emphasise the similarities between the Carboniferous Piesberg Quarry in Germany and the Mazon Creek Lagerstätte in North America. Palaeontologia Electronica, 25(1):a2. https://doi.org/10.26879/1051 palaeo-electronica.org/content/2022/3506-eumalacostracan-from-piesberg 
carolin.haug@palaeo-evo-devo.info

Angelika Leipner. Museum am Schölerberg, Klaus-Strick-Weg 10, 49082 Osnabrück, Germany. leipner@osnabrueck.de

Joachim T. Haug. LMU Munich, Faculty of Biology, Grosshaderner Str. 2, 82152 Planegg-Martinsried, Germany, and LMU Munich, GeoBio-Center, Richard-Wagner-Str. 10, 80333 München, Germany. joachim.haug@palaeo-evo-devo.info

Keywords: Eumalacostraca; Konservat-Lagerstätte; Peracarida; Pygocephalomorpha; Upper Carboniferous

Submission: 10 December 2019. Acceptance: 22 December 2022.

\section{INTRODUCTION}

The Piesberg quarry, near Osnabrück (Lower Saxony, Northwestern Germany), is famous for exceptionally preserved plant remains. Fossils of Euarthropoda have been found associated with more or less fragmented plant remains. The faunal elements represent various major groups, such as Scorpionida (Dunlop et al., 2008), Xiphosurida (Schultka, 2000; Haug et al., 2012), and especially Insecta, including immature specimens (Haug et al., 2013; Nel et al., 2013; Hörnig et al., 2014) and many winged adults (e.g., Brauckmann and Herd, 2007; Zessin, 2008; Brauckmann et al., 2021; Dvořák et al. 2021; Zessin et al., 2021a,b). Crustaceans other than Insecta are quite rare and mostly limited to small-sized entomostracan forms (e.g., Braun, 1997; Leipner and Chellouche, 2019). Eumalacostracans were unknown at the Piesberg quarry, yet recently, records of a pygocephalomorphan and of two different species of syncaridans were reported (Leipner and Chellouche, 2019; Wrede et al., 2019).

This low number of eumalacostracan fossils at the Piesberg quarry is surprising, as other Carboniferous deposits have provided a variety of fossils of different lineages of Eumalacostraca (Schram, 1981). From the groups recently reported from the Piesberg, representatives of Syncarida are found today in fresh and mainly groundwater environments in all continents, except for Antarctica (Camacho and Valdecasas, 2008); as for pygocephalomorphans, they are fossil crustaceans with shrimp- to lobster-like appearance that were a common element of near marine and deltaic assemblages from the Late Devonian to the Cisuralian (Early Permian) (Taylor et al., 1998; Gueriau et al., 2014). Fossils generally accepted as representatives of Pygocephalomorpha have already been interpreted as representatives of Peracarida (Jones et al., 2016), but also of Decapoda (Clark, 2013). Pygocephalomorpha potentially refers to a non-monophyletic assemblage of species, part of the early diversification of Caridoida (Jones et al., 2016), i.e., the group characterized by a tail-flip reaction (Richter and Scholtz, 2001).

Here we describe a pygocephalomorphan crustacean from the Piesberg quarry and compare it to the well-known pygocephalomorphan species Anthracaris gracilis (Meek and Worthen, 1865), reported previously from the Konservat-Lagerstätten Mazon Creek of Illinois, U.S.A., and Bickershaw, Lancashire, England. We summarize the similarities among these faunas and present an overview of the distribution of eumalacostracan crustaceans from Carboniferous deposits of North America, the UK, and continental Europe.

\section{MATERIAL AND METHODS}

\section{Material}

Five fossil specimens of crustaceans were collected from the Piesberg quarry, near Osnabrück, Lower Saxony, Germany, four of them by Michael Sowiak, Glandorf. All of the fossils are deposited in the palaeontological collection of the Museum am Schölerberg (MAS Pal.) in Osnabrück under collection numbers: MAS Pal. coll. Sowiak $1.756 \mathrm{~A} / \mathrm{B}$ (part and counterpart of isolated pleon, dorsal preservation), MAS Pal. coll. Sowiak $1.228 \mathrm{~A} / \mathrm{B}$ (part and counterpart of isolated shield, dorsal preservation), MAS Pal. coll. Sowiak 1.587A/B (part and counterpart of isolated shield, dorsal preservation), MAS Pal. coll. Sowiak $1.529 \mathrm{~A} / \mathrm{B}$ (part and counterpart of head, thorax, appendages and part of pleon, ventral preservation), and MAS Pal.590-2 (isolated shield, dorsal preservation).

\section{Geology}

The Piesberg quarry exposes an Upper Carboniferous succession of alternate beds of sandstones (coarse to conglomeratic), siltstones, and 
claystones, divided by coal seams (see Haug et al., 2013 for a lithostratigraphic profile). The crustaceans have been recorded in a layer of claystone on top of the most basal coal seam (Zweibänke). The Zweibänke coal seam marks the base of the Westphalian D stage (in European system = Moscovian stage, Middle Pennsylvanian, on the International Chronostratigraphic Chart; Dunlop et al., 2008), about 315.2 Ma to $307 \mathrm{Ma}$ (Cohen et al., 2013). From the same layer in which the crustacean specimens were found, there are many fossils of other groups of Euarthropoda, such as Euchelicerata (Xiphosurida, Scorpionida, Trigonotarbida, Phalangiotarbida), Diplopoda, and Insecta (Wrede et al., 2019). Additionally, other groups of animals are represented such as Bivalvia (freshwater forms) and even Neognathostomata (by actinopterygian fish scales and shark egg capsules) (Wrede et al., 2019). From the Zweibänke coal seam also autochthonous stems with roots of lycopods are known (Haug et al., 2013).

\section{Imaging Methods}

The fossils from the Piesberg quarry have been documented with a digital microscope, Keyence VHX-6000, which automatically generates composite images. To achieve these, it combines images of the same area with different focus levels into one sharp image, and in the following step it combines several adjacent areas into one large panoramatic image.

Different light settings were used: besides unpolarized ring light and co-axial light, also polarized co-axial light was applied, with a polarization filter built in the microscope and a perpendicularly oriented filter placed in front of the lens, to enhance the contrast and avoid reflections (Haug et al., 2011). The contrast of the resulting image was further enhanced through optimisation of the histogram ("Levels" tool) in Photoshop Elements 11. Using Inkscape (free and open-source software), we overlaid and blended the images of part and counterpart of specimen 1.529-2A/B ("blend mode": Luminosity), in order to visualize all structures preserved; yet, this resulted in some artifacts generated by the fissure plane of the sample, but which did not affect most parts of the body.

\section{Measurements}

We took measurements of three isolated shields collected at the Piesberg quarry and from shields of published representatives of Pygocephalomorpha to obtain a morphometric comparison for the shields (Appendix 1). The measurements taken

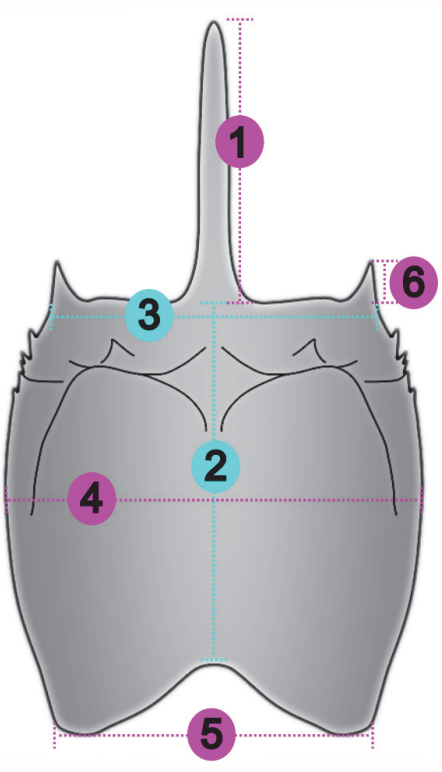

FIGURE 1. Schematic drawing of a pygocephalomorphan shield in dorsal aspect, showing the measurements taken for the morphometric analysis. 1: Length of rostrum, 2: Length of shield, 3: Width of anterior (outer) margin, 4: Medial width, 5: Width of posterior margin, 6: Length of antero-lateral spine.

from the shield were (Figure 1): 1) the length of the rostrum from the proximal region to the tip of the rostrum; 2 ) the length of the shield in the mid-sagittal plane from the proximal region of the rostrum to the mid-posterior margin of the shield; 3 ) the width of the anterior (outer) margin, distance between the lateral margins of the antero-lateral spines; 4) the median width, distance between the lateral margins taken at the point of maximum width; 5) the width of the posterior margin, distance between the postero-lateral shield corners; and 6) the length of the antero-lateral spine from the proximal region to the tip of the antero-lateral spine. For the shields with only one of the lateral margins preserved, we took measurements from the preserved margin until the mid-sagittal plane and duplicated the value.

For the measurements of the Piesberg specimens, we used the measure tool of the Keyence VHX-6000_950F communication software. The measurements from shields of Anthracaris gracilis were taken from published literature (Brooks, 1962, text-pl. 3d). The values were put into a spread sheet and then normalized, dividing each value by the largest one, and a plot of the normalized values was generated. The plot was redrawn in Inkscape. 


\section{Drawings}

Restoration drawings were made using Inkscape and then optimized in Photoshop Elements. The restoration of Pygocephalus cooperi Huxley, 1857 was based on images of the syntype deposited at the Manchester Museum, specimen MANUM L.10221, available on "The GB3D Type Fossils Online project" website (available at http:// www.3d-fossils.ac.uk). The restoration of the shield of Pygocephalus dubius (Prestwich, 1840) and P. cooperi were based on Schram (1979, fig. 39c and $39 a$, respectively), the shield of Anthracaris gracilis was based on images and restorations from the literature (Brooks, 1962, pl. 30, fig. 3, pl. 32, fig. 2, pl. 39, fig. 1). Only the better-preserved side of the specimens was drawn and then mirrored.

\section{Carboniferous Eumalacostracans}

For comparison to other eumalacostracan faunas, we made a list of eumalacostracan records from the Carboniferous of continental Europe, the UK, and North America from the literature (Appendix 2 and 3). Furthermore, we downloaded records from the digital repositories Paleobiology Database (PaleoDB, 2021, records identified as "occurrences") and World Register of Marine Species (WoRMS, 2021). In this case, we cross-checked the references so that if there is more than one occurrence of the same species in the same deposit, we kept only one occurrence, but both references.

The geographical coordinates were retrieved from different methods. For each occurrence we used its correspondent coordinate, when reported, from the literature or from the digital repositories. For the records from the UK that we mainly had the name of the location of the outcrop, we used the British National Grid online tool (available at https:/ /britishnationalgrid.uk/) to get an approximation of the original location. The maps and resulting plots were made using $\mathrm{R}$ environment and Inkscape for visual improvement.

\section{RESULTS}

\section{Description}

As stated above, the specimens represent different parts of a crustacean. To avoid description of a new species based only on isolated remains, we considered the samples with isolated remains preserved, such as shields and pleon (respectively MAS Pal. coll. Sowiak 1.228A/B, MAS Pal. 590-2, MAS Pal. coll. Sowiak 1.756A/B), as belonging to the same species as the more complete specimen
(MAS Pal. coll. Sowiak 1.529A/B) used for description of the functional head, thorax, and respective appendages. This decision is supported by measurements made on the isolated pieces, which are compatible with the size of the more complete specimen. We are aware of the fact that this condition may change as a result of new samples and further investigation. We present the description of each individual sample separately, accompanied by the collection number and portion of body preserved.

General characteristics. Dorso-ventrally compressed remains of lobster-like crustacean, preserved in dorso-ventral aspect (Figure 2).

MAS Pal. coll. Sowiak 1.228A/B, shield (dorsal aspect). Shield slightly longer than wide; surface smooth; anterior rim drawn out into long rostrum, shorter than the length of main part of shield, $0.5 x$; pair of large antero-lateral spines directing forward, circa $0.25 x$ the length of the rostrum; six pairs of lateral spines, first pair largest, $0.3 x$ the length of antero-lateral spines, subsequent pairs slightly decreasing in size. Posterior margin of shield concave (Figure $3 \mathrm{~A}-\mathrm{D}$ ), partially incomplete due to preservation.

MAS Pal. 590-2, shield (dorsal aspect). Ovalshaped shield; longer than wide; surface smooth; only proximal portion of the rostrum preserved, broken off distally; pair of large antero-lateral spines directed forward, $1.04 \mathrm{~mm}$ in length; eight pairs of lateral spines, first pair largest, $0.3 x$ the length of antero-lateral spines, subsequent pairs slightly decreasing in size (Figures $3 \mathrm{E}-\mathrm{F}, 4 \mathrm{H}$ ). Posterior margin of shield concave.

MAS Pal. coll. Sowiak 1.587A/B, shield (dorsal aspect). Shield slightly longer than wide; long rostrum, $0.5 x$ the length of the shield (Figure 4G); pair of large antero-lateral spines directed forward, circa $0.2 x$ the length of the rostrum; four pairs of lateral spines, first pair largest, $0.3 x$ the length of antero-lateral spine, subsequent pairs slightly decreasing in size (Figure 4F); diagonal groove on the anterior margin at the proximal region of the rostrum; concave groove on anterior third of the shield, reaching the proximal region of second lateral spine laterally and the anterior third of the shield medially; disperse punctuations on lateral surfaces; posterior margin of shield concave (Figure $4 \mathrm{~A}-\mathrm{E})$, possibly deformed due to compression during preservation.

MAS Pal. coll. Sowiak 1.529A/B, functional head, appendages of the functional head, thorax, thoracic appendages (ventral aspect). Head composed of six segments, recognized by 

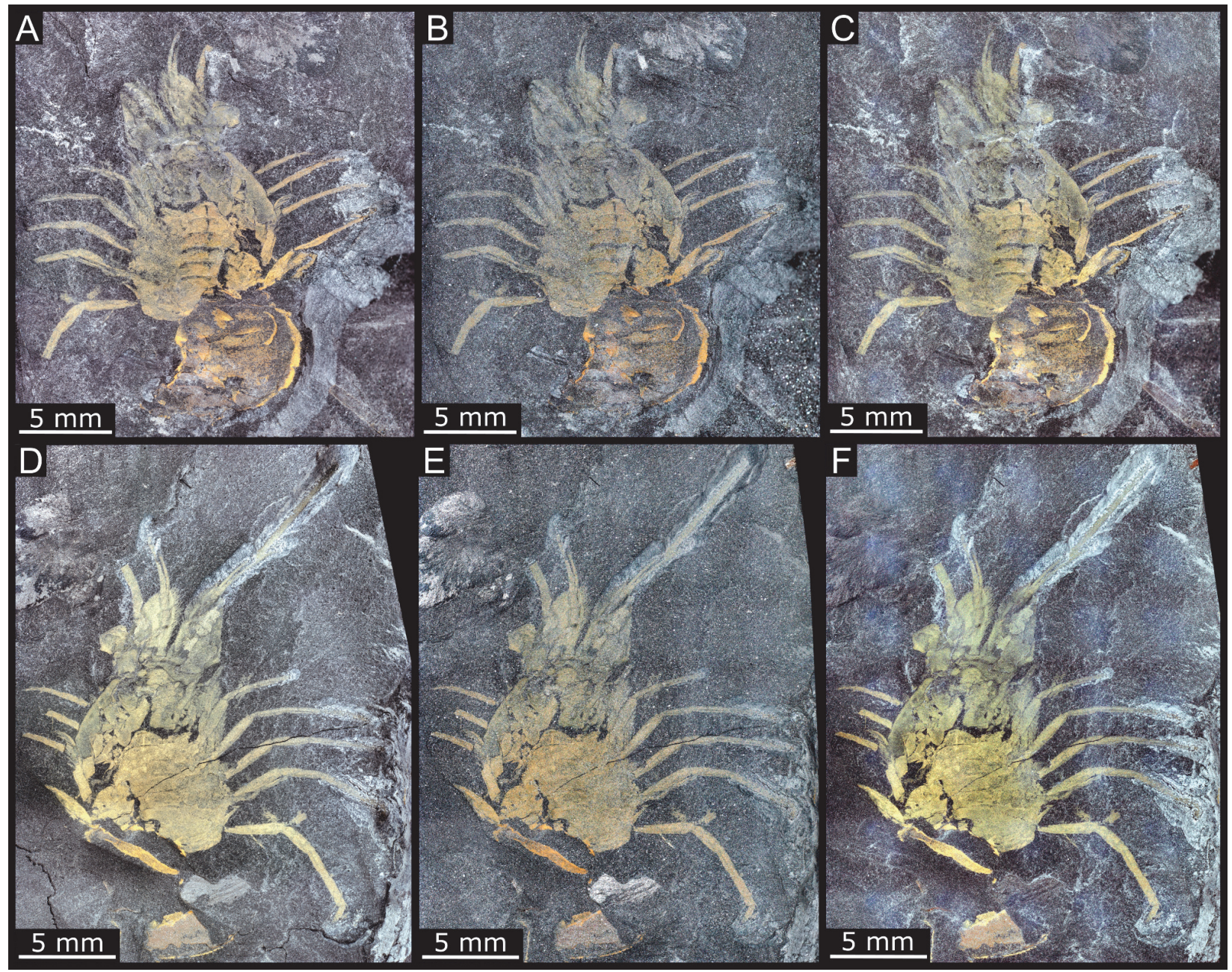

FIGURE 2. Anthracaris gracilis (Meek and Worthen, 1865) from the Carboniferous of Germany. Digital microscopy image of part $(A-C)$ and counterpart (D-F) (specimen 1.529), in ventral view. (A, D) Ring light. (B, D) non-polarized coaxial light. (C, F) polarized co-axial light.

respective external structures: lateral eyes, antennula, antenna, mandible, maxillula, maxilla (Figure 5).

Lateral eyes with peduncle. Only distal part of the peduncle preserved; large and rounded cornea region directed laterally.

Antennula with three apparent elements. Element 1 long, elements 2 and 3 shorter than 1, 0.5x. Element 3 bearing two multi-annulated flagella.

Antenna with broad basipod bearing endopod and exopod. Endopod of antenna with three elements, more slender than basipod, $0.3 \mathrm{x}$. Element 1 short, elements 2 and 3 of about same length, longer than 1, 2x. Element 3 bearing single multi-annulated flagellum. Exopod as a flat and broad scaphocerite, about same width as basipod, as long as the three elements of endopod. Inner margins of scaphocerite with setae, from the distal edge until about middle of the margin, in antero- posterior direction. Outer margin apparently smooth.

Labrum half-circle shaped, rounded edge pointed anteriorly. Remains of mouth parts preserved; putative individual elements discernible by position. Putative mandibles roughly sub-rectangular proximally, no distal part, i.e., mandibular palp, present. Putative maxillula slender. Putative maxilla apparently large, with a sub-rectangular proximal region (possible basipod?) medially drawn out into possible endite; two distal protrusions, a larger and rounded one medially (possible endopod?) and a slender one more laterally (exopod?).

Eight thoracic sternites present. Thoracic sternite 1 partially preserved by only a slender remain. Thoracic sternites 2-8 of roughly trapezoidal shape, around the same length, increasing in width posteriorly. Laterally to each side of each sternite a thoracic appendage arises. 


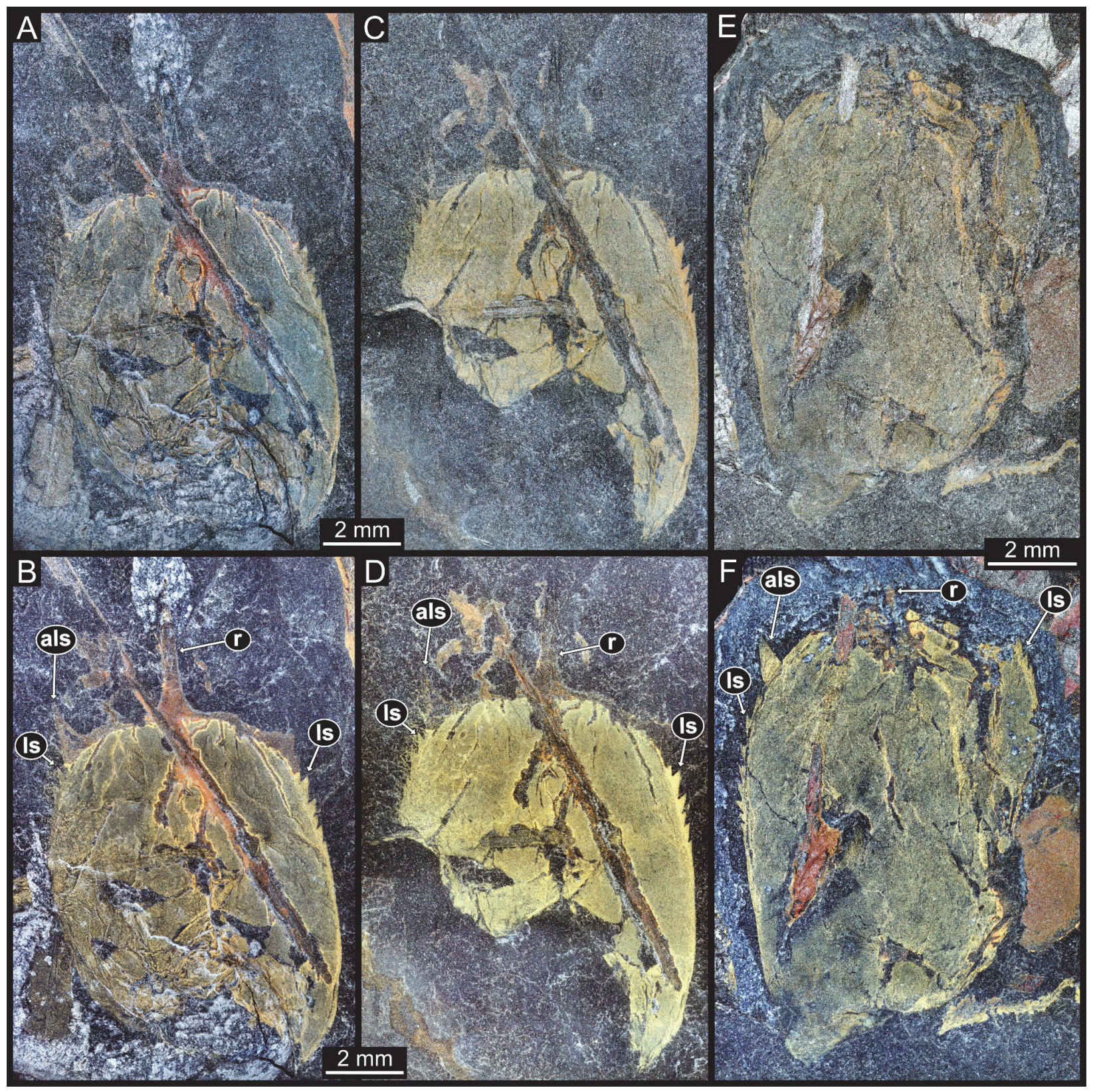

FIGURE 3. Anthracaris gracilis (Meek and Worthen, 1865) from the Carboniferous of Germany. Digital microscopy images of shields. (A-D) Dorsal view of specimen 1.228. (A, B) Part. (C, D) Counterpart. (E, F) Dorsal view of specimen Pal590-2. (A, C, E) Non-polarized co-axial light. (B, D, F) Polarized co-axial light. Images of the counterparts are mirrored. Abbreviations: als = antero-lateral spine; Is = lateral spine; $r=$ rostrum.

Thoracic appendage 1 (thoracopod 1) differs in shape from remaining thoracic appendages. Proximal element enlarged and stout, barrelshaped, possibly a coxa with enlarged median endite; element 2 (basipod) short, bearing endopod and exopod; endopod with elements 3 (ischium) and 4 (merus) preserved; further distal parts missing; exopod leaf-like, smooth margins.

Thoracic appendages 2-8 all sub-equal, increasing in length posteriorly. Proximal element 1 (coxa), rounded and short; basipod tubular, longer than coxa, 3x, bearing two rami, endopod and exopod. Endopod composed of five elements, from proximal to distal: elongated ischium, longer than coxa, $6 x$, increasing in width from anterior to posterior margins, $1.5 \mathrm{x}$; merus, carpus and propodus of around same length, longer than coxa, about $4 x$, anterior margin of propodus with spine-like structure latero-distally; dactylus pointed, longer than coxa, 2x. Exopod with two regions. Proximal region 


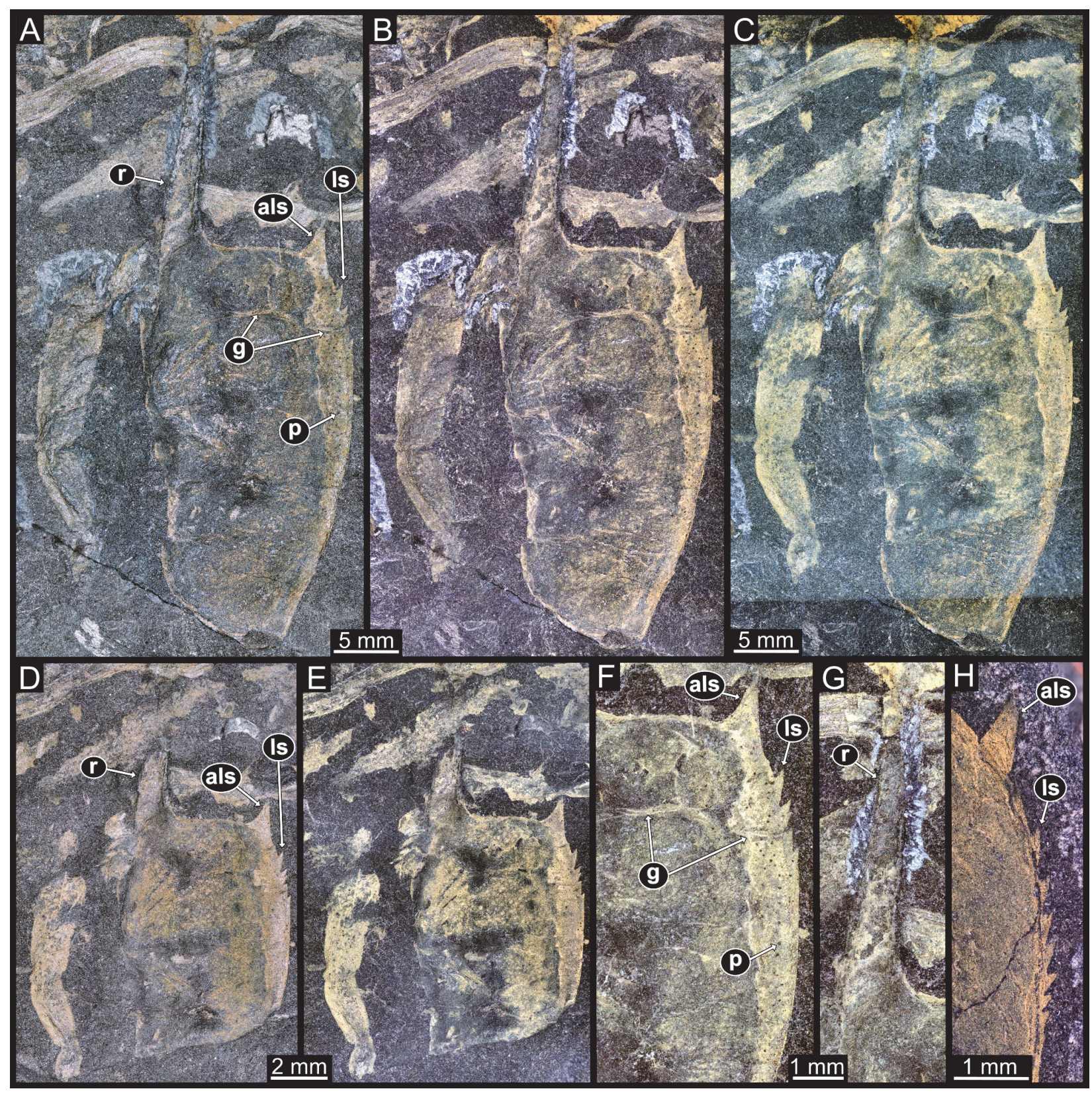

FIGURE 4. Anthracaris gracilis (Meek and Worthen, 1865) from the Carboniferous of Germany. Digital microscopy images of shields. (A-G) Specimen 1.587 in dorsal view. (A-C) Part. (D, E) Counterpart. (A, D) Non-polarized co-axial light. (B, E) Polarized co-axial light. (C) Ring light. (F) Detail of $B$, antero-lateral shield corner. ( $G$ ) Detail of $B$, rostrum. $(\mathrm{H})$ Detail of Pal590-2, antero-lateral shield corner, mirrored. Images of the counterpart are mirrored. Abbreviations: als = antero-lateral spine; $g=$ groove; $l s=$ lateral spine; $p=$ punctuations; $r=$ rostrum.

roughly rectangular in anterior view, longer than coxa, 3x. Distal region as long as basipod, setose, multi-annulated (Figure 6F-H).

MAS Pal. coll. Sowiak 1.756A/B, pleon (dorsal aspect). Mostly six tergites, indicating the six pleon segments, and tail fan preserved (Figure 6A-E). Tergites roughly rectangular and subequal in size. Remains of pleopods from pleon segments 1,2 , and 5 preserved. Basipods with rounded edges, bearing two elongated and slender elements. Tail fan formed by uropods (pleopods 6) and telson. Basipod of uropods about the same length as the pleon segments. Endopod large, oval-shaped, lateral margins smooth, distal margins densely setose. Exopod oval-shaped, slender, lateral margins smooth, posterior margins densely setose, concave transversal suture on the posterior third of exopod, wider than endopod, $2 x$. 


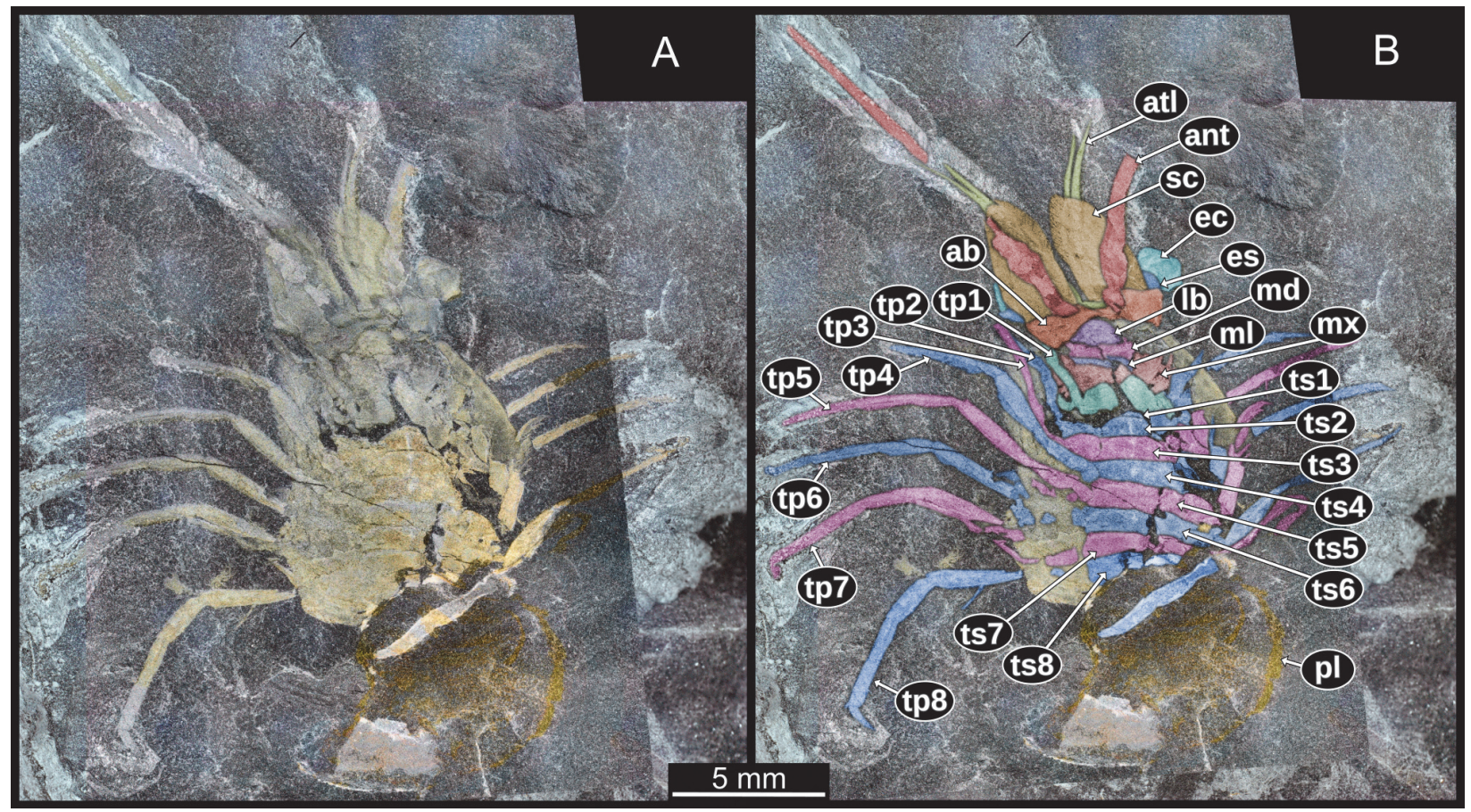

FIGURE 5. Anthracaris gracilis (Meek and Worthen, 1865) from the Carboniferous of Germany. (A) Virtually overlaid part and counterpart of specimen 1.529. (B) Same as A, but structures colour marked. Abbreviations: ab = antenna basipod; ant = antenna; atl = antennula; ec = eye cornea; es = eye stalk; lb = labrum; $\mathrm{md}=$ mandible; $\mathrm{ml}=$ maxillula; $\mathrm{mx}=$ maxilla; $\mathrm{pl}=$ pleon; $\mathrm{sc}=$ scaphocerite; $\mathrm{tp} 1-8=$ thoracopod $1-8 ;$ ts $1-8=$ thoracic segment $1-8$.

Telson longer than pleon segments, $2 x$. Roughly square-shaped, anterior margin straight, lateral margins slightly convex, posterior margin with three concavities. Each marginal concavity bearing a movable ellipsoidal structure. Lateral margins of these structures smooth, posterior margin densely setose. Middle concavity with remains of a comparable structure; preservation does not allow to determine the exact shape (Figure 6A-E).

\section{Morphometric Comparison}

The three isolated shields from the Piesberg quarry do not present significant differences in overall morphology. When plotting the shields from the Piesberg quarry with specimens of Anthracaris gracilis measured by Brooks (1962) (Figure 7), we see that the overall morphology is very similar. The rostrum of many specimens, e.g., specimen MAS Pal. 590-2 could not be obtained because it is broken off distally (also the case for many of the specimens in Brooks, 1962). Most of the shields are slightly longer than wide. Only the smallest shield (MAS Pal. coll. Sowiak 1.228A/B) is as long as wide.

\section{DISCUSSION}

\section{Phylogenetic Interpretation: The Coarse Frame}

The specimens from the Piesberg quarry have a combination of two characters that identifies them with certainty as representatives of Eumalacostraca: 1) a scaphocerite, i.e., a paddle-shaped exopod on the antenna (sample MAS Pal. coll. Sowiak 1.529A/B, Figure 5), and 2) telson and uropods forming a tail fan (sample MAS Pal. coll. Sowiak 1.756A/B, Figure 6A-E). For isolated shields, it often remains difficult to decide to which group they belong, as the presence of a head shield is a plesiomorphic condition within Eucrustacea (Walossek, 1999), and a prominent head shield might be plesiomorphic for Eumalacostraca, or at least for certain lineages. However, the fixed elongated rostrum and spines of the shields from the Piesberg specimens resemble shields of some species of Pygocephalomorpha. Likewise, the specimen with ventral preservation of head appendages and thorax (MAS Pal. coll. Sowiak $1.529 \mathrm{~A} / \mathrm{B}$, Figure 5) and the isolated tail fan (MAS Pal. coll. Sowiak 1.756A/B, Figure 6A-E) show morphological similarities to representatives of Pygocephalomorpha, such as a prominent thoracic midline of sub-trapezoidal sternites, thoracic 


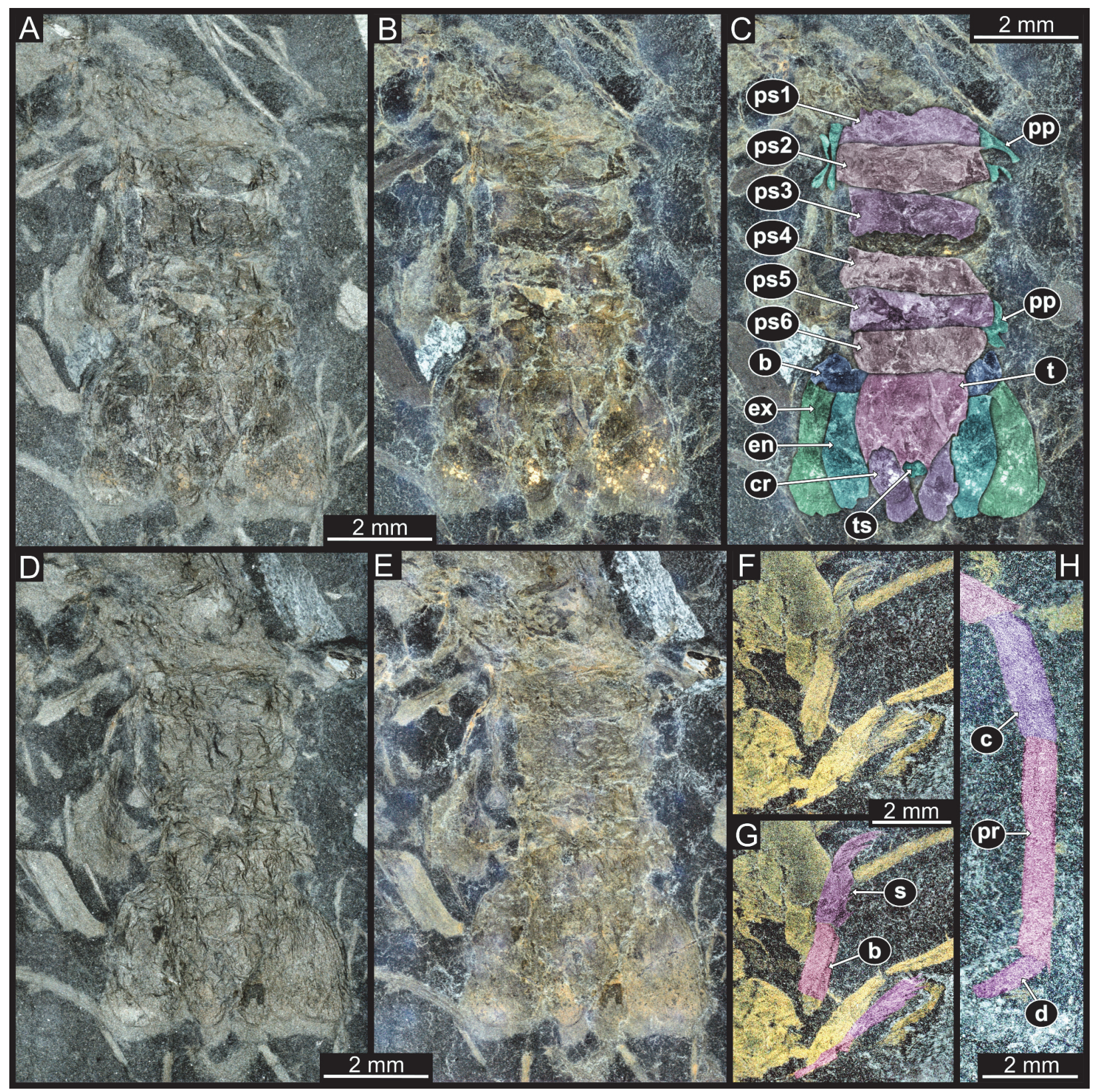

FIGURE 6. Anthracaris gracilis (Meek and Worthen, 1865) from the Carboniferous of Germany. (A-E) Digital microscopy image of isolated pleon in dorsal view of specimen 1.756. (A, B) Part. (C) Same as B, but structures colour marked. (D, E) Counterpart. (A, D) Non-polarized co-axial light. (B, E) Polarized co-axial light. Images of the counterpart are mirrored. $(\mathrm{F}-\mathrm{H})$ Details of specimen 1.529. (F) Detail of exopods of thoracic appendage. (G) Same as $F$, but colour marked. $(\mathrm{H})$ Detail of the distal portion of an endopod of thoracic appendage, colour marked. Abbreviations: $b=$ basipod; $c$ = carpus; $c r=$ caudal ramus; $d$ = dactylus; en = endopod; ex = exopod; $p p=$ pleopod; $p s 1-6=$ pleon segment $1-6 ; \mathrm{pr}=$ propodus; $\mathrm{s}=$ setae; $\mathrm{t}=$ telson; $\mathrm{ts}=$ telson spine.

appendages with exopods, and movable structures on the telson.

Out of the 28 formally described species of Pygocephalomorpha in the literature, the specimens from the Piesberg quarry show most morphological similarities to Pygocephalus cooperi, $P$. dubius, Anthracaris gracilis, and Mamayocaris jaskoskii Schram, 1974, detailed as follows.

Pygocephalus cooperi and $P$. dubius have been recorded in deposits from the UK commonly known as Coal Measures (Schram, 1979a). Deposited during the Upper Carboniferous, the Coal Measures comprise a sequence of fluvio-del- 


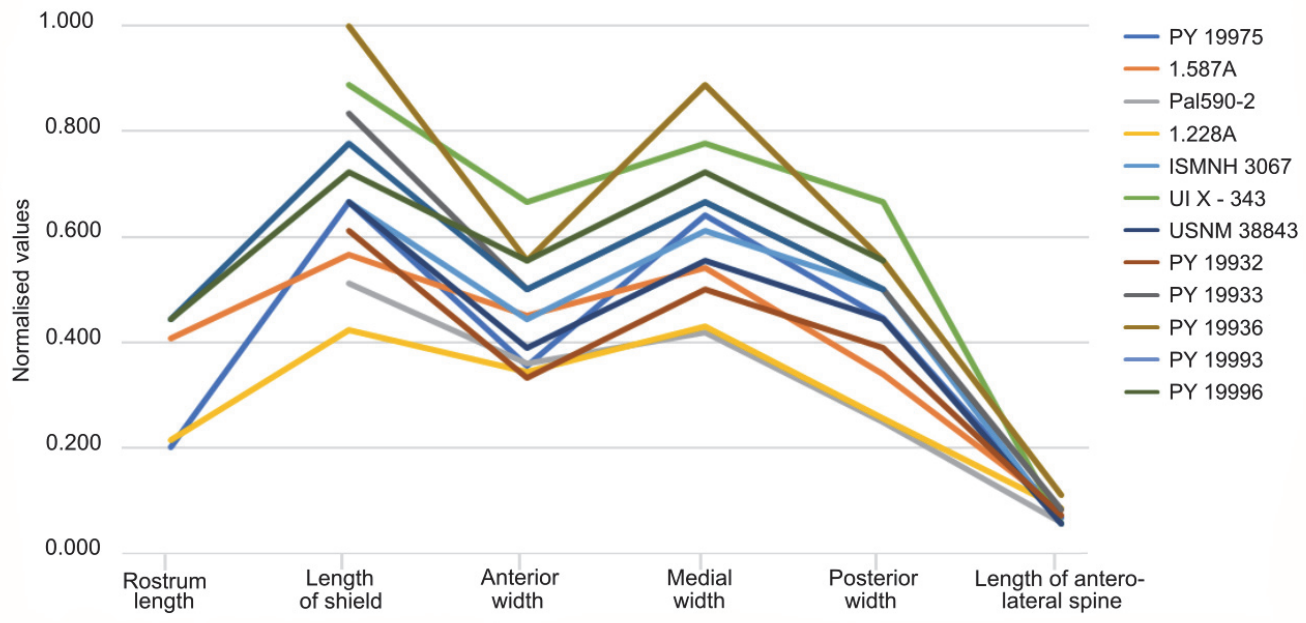

FIGURE 7. Plot of the eumalacostracan shields of Anthracaris gracilis (Meek and Worthen, 1865) from the Carboniferous of Germany (1.587A, Pal.590-2, 1.228A) and of A. gracilis from Mazon Creek, USA. Values for $A$. gracilis from Brooks (1962).

taic sediments inter-bedded with layers of coal. The records of Pygocephalus cooperi and $P$. dubius come from the basal and middle portions of the Coal Measures, corresponding to the Lower to Middle Pennsylvanian (stages Bashkirian to Moscovian in IUGS or Westphalian A and B in the European system). The only differences among these two species are features of the shield (Brooks, 1962; Schram, 1974, 1979a) (Figure 8E, F). On the lateral margins of the shield of $P$. cooperi, there are six or seven lateral spines positioned anteriorly, and the surface of the shield is smooth. In $P$. dubius, the entire lateral margins have spines, the surface of the shield is punctate, and a mid-dorsal keel runs from anterior to posterior (Figure 8F). Brooks (1962) argued that differences in the number of lateral spines and surface ornamentation (small punctae) of the shield are not reliable characters to differentiate species, so he synonymized both species. He based his argument on the analysis of shields of Anthracaris gracilis (Figure 8D), where the number of lateral spines varies greatly, and no discrete pattern can be recognized. Later, a reinterpretation of both species of Pygocephalus Huxley, 1857 has led to their separation as two valid species (Schram, 1974), and so the situation has remained since then.

Preservation aspects can also affect the general appearance of the shield (Pazinato et al., 2018), thus erecting different species based solely on features of the shield can lead to overestimation of species diversity. Therefore, until more speci-
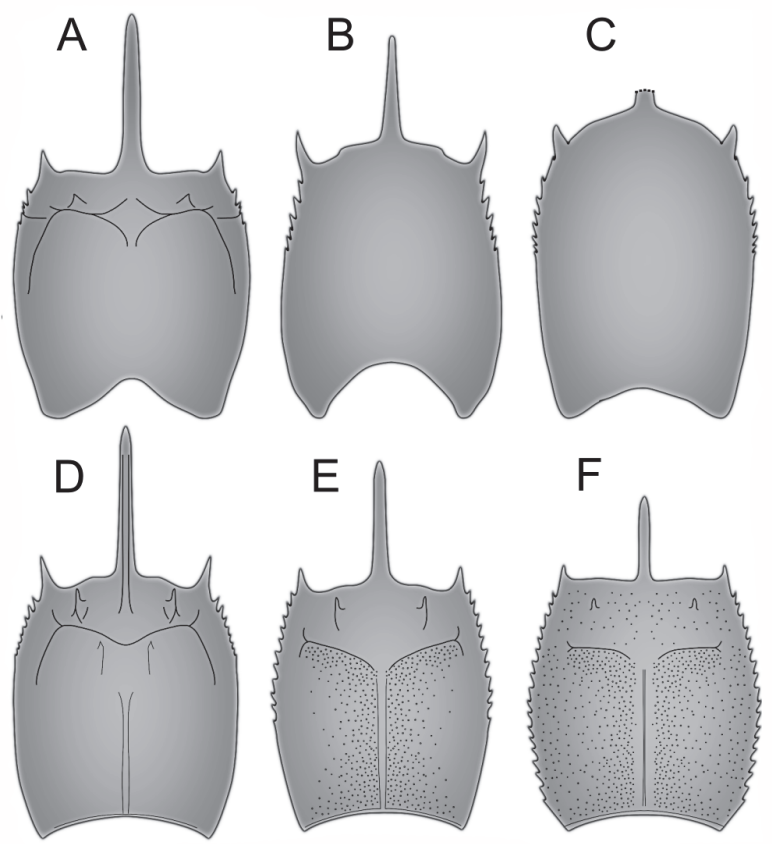

FIGURE 8. Restoration drawings of shields of pygocephalmorphans. (A) Specimen 1.587, (B) 1.228 and (C) Pal.590-2 of Anthracaris gracilis (Meek and Worthen, 1865) from the Carboniferous of Germany. (D) Anthracaris gracilis, based on Brooks (1962, pl. 32, fig. 2). (E) Pygocephalus cooperi Huxley, 1857, based on Schram (1979, fig. 39a). (F) Pygocephalus dubius (Prestwich, 1840), based on Schram (1979, fig. 39c). 

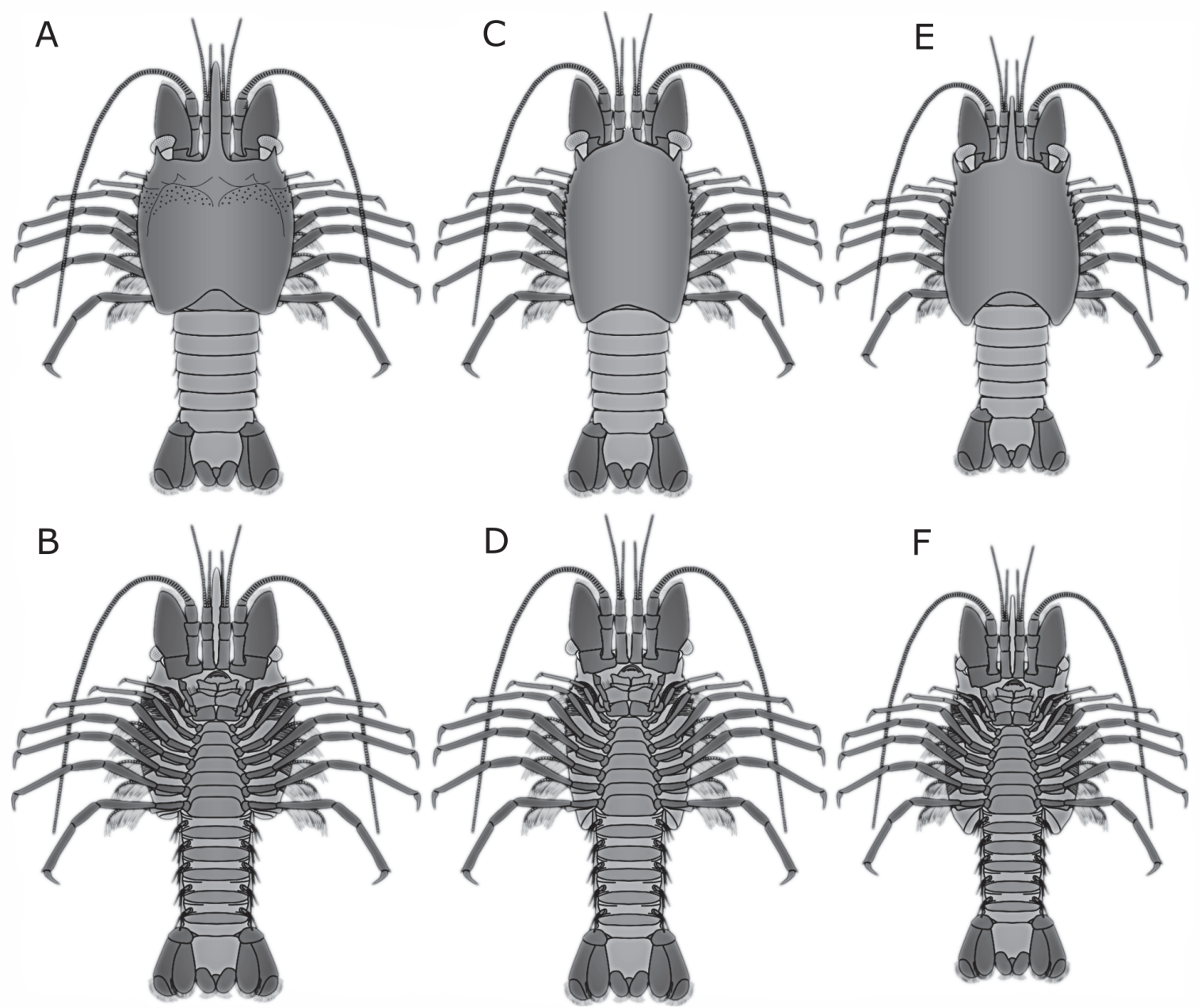

FIGURE 9. Restoration drawings of Anthracaris gracilis (Meek and Worthen, 1865) from the Carboniferous of Germany with the three different shields recovered. (A, C, E) Dorsal aspect. (B, D, F) Ventral aspect. (A, B) Specimen 1.587. (C, D) Specimen Pal.590-2, the rostrum is broken off. (E, F) Specimen 1.228.

mens become available, the three different shields found at the same horizon of the Piesberg quarry as the more complete specimen (MAS Pal. coll. Sowiak $1.529 \mathrm{~A} / \mathrm{B}$ ) are considered here as representatives of the same species (Figure $8 \mathrm{~A}-\mathrm{C}$, Figure 9). Also, the situation in Pygocephalus should be carefully reconsidered.

In overall appearance the fossils from the Piesberg quarry resemble Pygocephalus cooperi, but there are some important differences. Thoracic appendages 1 and 2 of both Pygocephalus species have proximal elements enlarged, possibly representing drawn out endites of the coxae, also referred as 'gnathobases' (Brooks, 1962; Schram, 1979a).

Consequently, thoracic sternites 1 and 2 are not visible, but covered by these structures (Figure 10E, F).
On specimen MAS Pal. coll. Sowiak 1.529A/B from the Piesberg quarry, thoracic sternite 1 is only represented by a slender remain closely adjacent to the well visible thoracic sternite 2 . Only the first pair of thoracic appendages appears to have enlarged endites. Thoracic sternites 2-8 increase gradually in width from anterior to posterior and the corresponding thoracic appendages have small, non-drawn-out, proximal elements (Figure 5). Species of Pygocephalus have two pairs of ellipsoidal structures on the telson, also referred as 'furcal lobes' in literature (Jones et al., 2016), while the specimen recorded from the Piesberg quarry possesses only one pair. Additionally, records of Pygocephalus remain restricted to stages Westphalian $A$ and Westphalian B in the European system, between approximately 318-314 million years ago, while the records from the Piesberg quarry come from the stage Westphalian D, circa of 311-307 

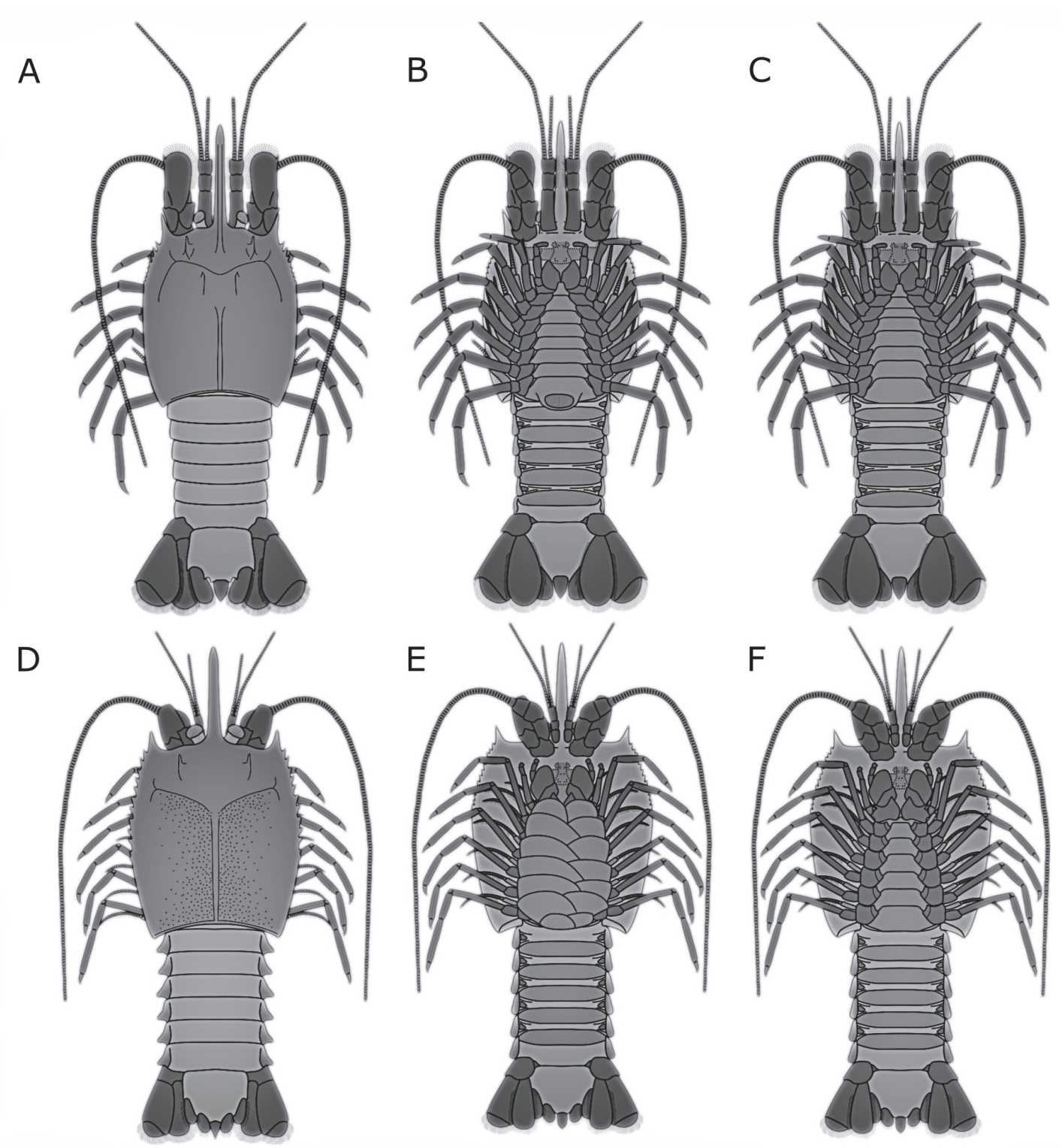

FIGURE 10. Restoration drawings of the pygocephalmorphan Anthracaris gracilis (Meek and Worthen, 1865) and Pygocephalus cooperi Huxley, 1857. (A-C) A. gracilis. (A) Dorsal aspect. (B) Ventral aspect of putative female, note the pouch on the last thorax segment. (C) Ventral aspect of putative male. (D-F) P. cooperi. (D) Dorsal aspect. (E) Ventral aspect of female with thorax sternites hidden by oostegites. (F) Putative male in ventral aspect.

million years ago. Thus, there is around 3 million years of time difference between the records from the UK and Germany.

Other quite similar-appearing species, Anthracaris gracilis and Mamayocaris jaskoskii, were described based on fossils found in fossiliferous concretions of the Mazon Creek Lagerstätte, in Illinois, USA. The deposit is part of the Francis Creek Shale Member of the Carbondale Formation, from the Middle to the Upper Pennsylvanian, with an age of 311-306 Ma (Clements et al., 2018). This age corresponds to the stages Moscovian to Kasi- movian in IUGS system, which matches Westphalian $D$ in the European system. Before we go further in comparison, we must add some taxonomic notes concerning both species.

\section{On The Taxonomic Status of Species of Pygocephalomorpha from Mazon Creek}

It is widespread in the literature that the Mazon Creek Lagerstätte has two differentiable characteristic faunas, the Essex fauna and the Braidwood fauna (Johnson and Richardson, 1966; Schram, 1974; Baird, 1990). The Essex fauna was 
thought to be restricted to marine organisms, while the Braidwood fauna has many records of freshwater and terrestrial organisms (Johnson and Richardson, 1966). Anthracaris gracilis is mainly known from the Braidwood fauna, while Mamayocaris jaskoskii was described from the marine Essex fauna (Schram, 1974).

In the original description of Mamayocaris jaskoskii, only one morphological difference from Anthracaris gracilis was noted: in lateral view, $M$. jaskoskii should lack 'hepatic spines' (Schram, 1974, p. 12, figure 1C), a pair of spines just below the line of the cervical groove. According to one of the images of M. jaskoskii (Schram, 1974, p. 14, figure 3 ) one could argue for the presence of such spines. Besides this unclear morphological difference, the other distinction between the two species is the fact of being recorded in different, yet adjacent, faunas (Schram, 1974).

The strict categorization into two distinct faunas is no longer supported. The Braidwood fauna seems formed simply by land organisms transported into a shallow brackish marine environment, as Mazon Creek is the product of a river deltaic depositional system (Clements et al., 2018). This no longer accepted categorization of two faunas for Mazon Creek, one mainly composed by marine and the other by inland/freshwater organisms, was a major argument for distinguishing the two species, hence it may suggest that Mamayocaris jaskoskii is merely a junior synonym of Anthracaris gracilis. A reinvestigation of the type material of the previous species is needed to resolve this issue. Nevertheless, for now we consider the distinctiveness of $M$. jaskoskii disputed and consider here only those specimens previously identified as $A$. gracilis for further comparison.

\section{Comparison of the New Fossils to Anthracaris gracilis}

Similarly, to the well-preserved specimen from the Piesberg quarry, Anthracaris gracilis from Mazon Creek has only the first pair of thoracic appendages with proximal drawn out endites. Although the reconstruction from the original description of the species (Brooks, 1962, text-pl. 2) shows the first two pairs of thoracic appendages with enlarged endites, this does not match the images of the fossils in the same publication (Brooks, 1962, pl. 30, fig. 3 and pl. 39, fig. 1). Therefore, our reconstruction is based mostly on these photographic images (Brooks, 1962, pl. 30, fig. 3 and pl. 39, fig. 1). Like the Piesberg fossil, $A$. gracilis also has only one pair of movable ellipsoi- dal structures on the telson. Although very similar, some differences can be identified between the already known material of $A$. gracilis and specimens from the Piesberg quarry, which we believe are the result of different preservation, and are explained here:

1) Anthracaris gracilis appears to have small compound eyes, contrasting with rather large, clearly pedunculate compound eyes in fossils from the Piesberg. Brooks (1962) stated that pedunculate eyes can be seen on one of the specimens that he analysed, but the specimen is not figured. However, his reconstruction of $A$. gracilis shows small pedunculate eyes, and we followed this representation in our reconstruction. This indicates that the seeming difference in the size and morphology of eyes is only a matter of preservation.

2) A ventral pouch-like structure on the last thoracic sternite (thoracic segment 8) was reported from some specimens of Anthracaris gracilis (Figure 10A-C), which Brooks (1962) described as a "seminal receptacle". These specimens would represent females. Such a structure is not present on the fossil from the Piesberg quarry. Unfortunately, this last thoracic sternite of the specimen from the Piesberg quarry is partially covered by the laterally preserved pleon, so the exact shape of the sternite is unknown. This difference may well correspond to a sexual dimorphism (Brooks, 1962; Schram, 1986), which explains the presence of this pouch-like structure on only some of the specimens recorded. This would mean that the specimen (MAS Pal. coll. Sowiak 1.587A/B) from the Piesberg quarry could represent a male.

3) The exopods are extremely setose in the fossil from the Piesberg quarry, which has not been recorded in Anthracaris gracilis. Thoracic exopods are usually delicate structures not readily preserved. In fact, the "setiferous" (Brooks, 1962, p. 186) part of the exopod is present on only one sample of $A$. gracilis (Brooks, 1962, pl. 39, fig. 2); this difference is therefore likely to be due to preservation.

4) The shape of the scaphocerite is more pointed in the specimen from the Piesberg quarry. Yet, it is also only rarely preserved in specimens of Anthracaris gracilis. Hence this difference might also be result of the mode of preservation. 
A

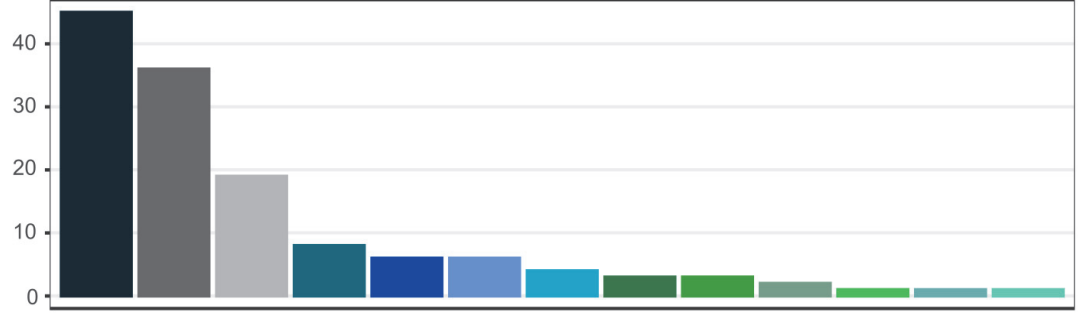

B

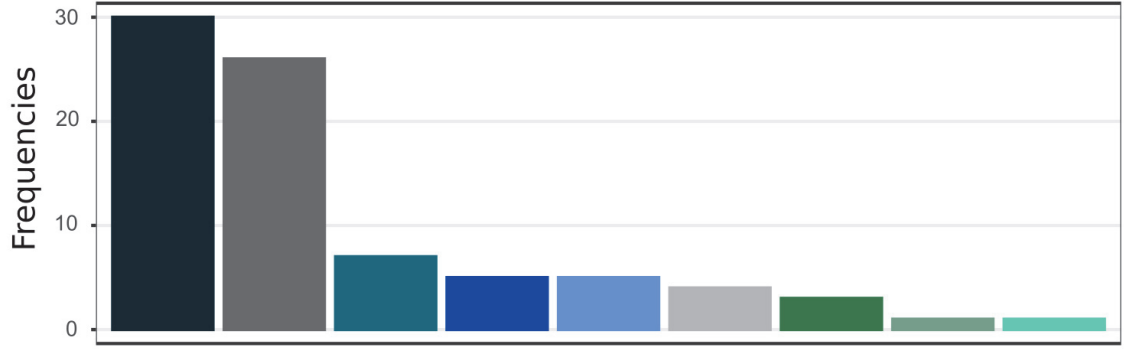

C

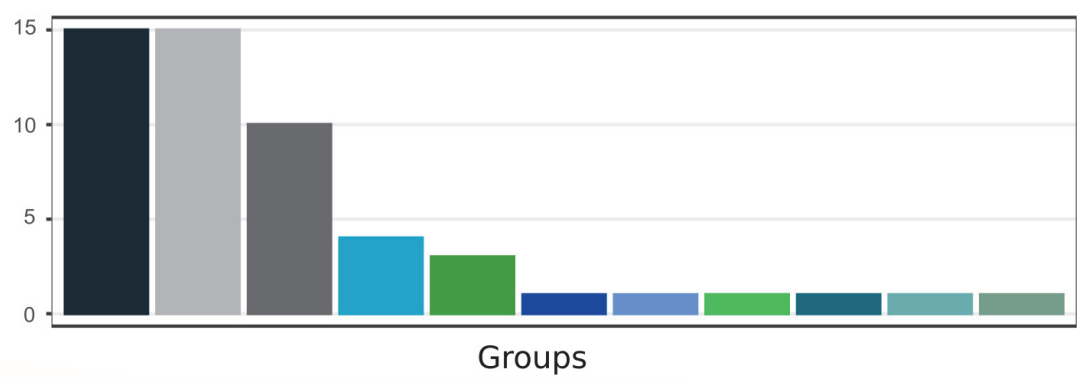

Hoplocarida

Pygocephalomorpha

Syncarida

Phyllocarida

Anthracophausiidae

Belotelsonidea

Lophogastrida

Schramocaris sp.

Isopoda

Tanaidacea

Palaeopalaemonoidea

Spelaeogriphacea

Waterstonellidae

FIGURE 11. Frequency plot of the distribution of ingroups of Eumalacostraca and of its sister-group Phyllocarida, during the Carboniferous (A) of North America, the UK and continental Europe, the Mississippian (B) and the Pennsylvanian $(\mathrm{C})$.

Therefore, the taxonomic treatment for the fossils from the Piesberg quarry is suggested as Anthracaris gracilis (Meek and Worthen, 1865).

\section{Eumalacostracan Faunas of Carboniferous Lagerstätten}

Carboniferous deposits of North America, the UK and continental Europe present many fossils that are morphologically and ecologically similar and therefore are useful for palaeogeographic comparisons. Due to the extensive literature on this subject and the scope of this work, we focus on records of Eumalacostraca of many, but not all, Carboniferous deposits and comparison of the faunal structures of three deposits which present records of Anthracaris gracilis.

In the Carboniferous, there are records from many groups of Eumalacostraca, such as Hoplocarida and Peracarida, with several representa- tives recorded in different sites of the Mississippian (Appendix 4) and the Pennsylvanian (Appendix 5). In Carboniferous deposits of the Northern hemisphere, there is a dominance of the group Hoplocarida, where the records of the Mississippian account for twice the number of records of the Pennsylvanian (Figure 11). Nowadays, Hoplocarida is represented only by the ingroup Stomatopoda, and it is morphologically (and possibly ecologically) less diverse than Carboniferous hoplocaridans, occurring in many marine habitats and being common in tropical and subtropical coastal waters (Schram et al., 2013). This drop in hoplocaridan records from the Carboniferous is also seen in records of Pygocephalomorpha, which become virtually extinct in the Permian. Otherwise, ingroups of Peracarida such as Isopoda, Lophogastrida, and Spelaeogriphacea apparently rose during the Pennsylvanian (Figure 11C). For 


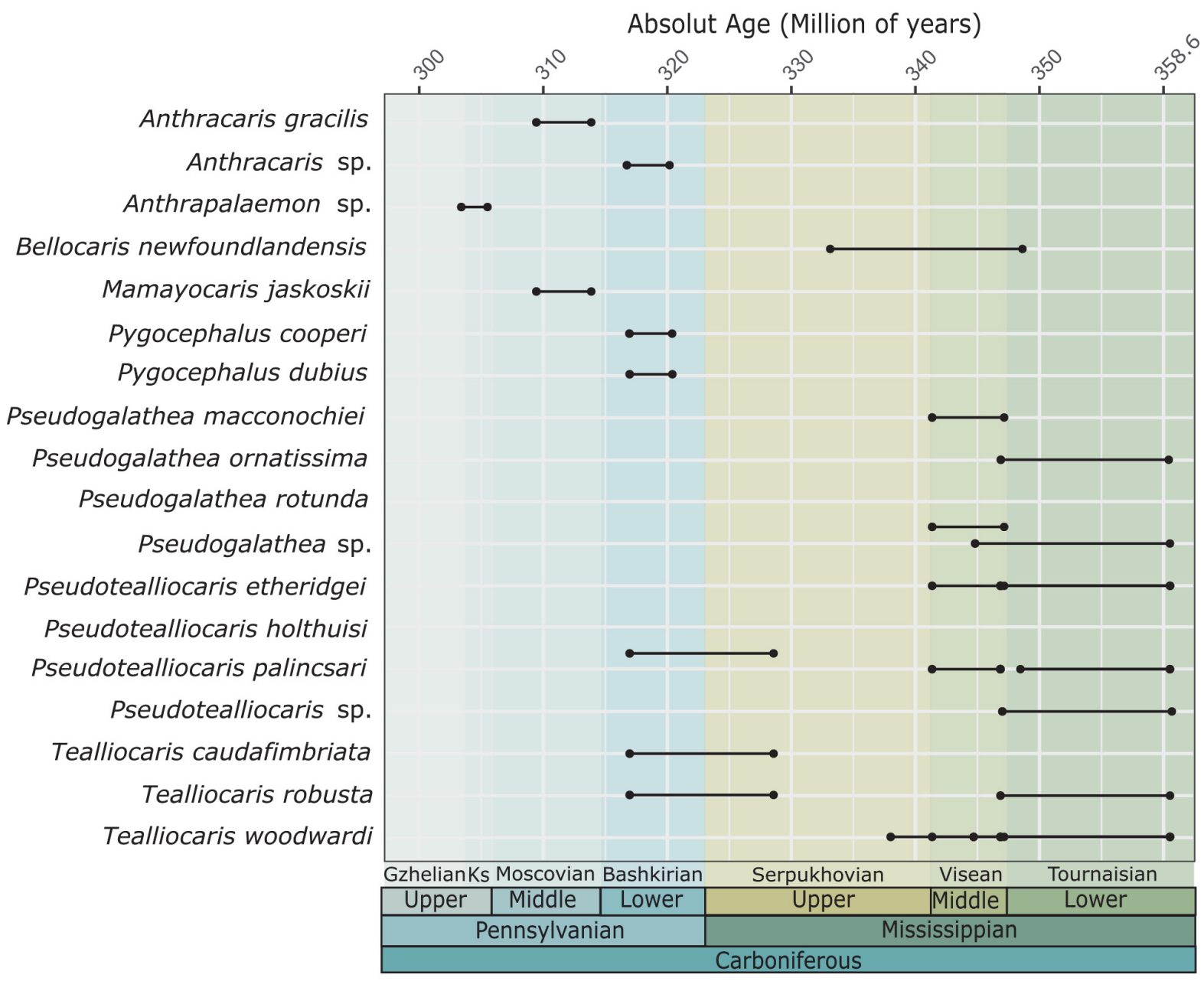

FIGURE 12. Time span of the species of Pygocephalomorpha during the Carboniferous of North America, the UK and continental Europe. Abbreviation: Ks, Kasimovian.

Tanaidacea, there is one record for the Mississippian and one for the Pennsylvanian (Appendix 46 ), and several records in the Mesozoic (Schädel et al., 2019).

For other larger eumalacostracan groups, Syncarida shows an impressive increase in number of records from the Mississippian to the Pennsylvanian (Figure 11C), more than three times. Eucarida is believed to be represented in the Pennsylvanian by Palaeopalaemon newberryi Whitfield, 1880 , possibly an early representative of Decapoda, which first appeared in the Devonian (Jones et al., 2018).

Other ingroups of Eumalacostraca, whose affinities are not well-understood and are only known by fossil species, such as Anthracophausiidae, Belotelsonidea, Waterstonellidae and the species group Schramocaris Clark, Gillespie, Morris, and Clayton, 2015, occur in a higher frequency in the Mississippian. The same is the case for representatives of Phyllocarida, the sister-group of Eumalacostraca (Richter and Scholtz, 2001).

Records of Pygocephalomorpha are of special interest here. The frequency of fossils ascribed to Pygocephalomorpha is higher by more than two times in the Mississippian than in the Pennsylvanian (Figure 11). Different species-groups are found during the course of the Carboniferous. In the Mississippian, there is record for the species Bellocaris newfoundlensis Fong, 1972, and the species-groups Pseudogalathea Peach, 1882, Pseudotealliocaris Brooks, 1962, and Tealliocaris Peach, 1908, the latter two have records until the beginning of the Pennsylvanian (Figure 12). In the Pennsylvanian, the fossils of Pygocephalomorpha are of the species-groups Pygocephalus and Anth- 
racaris (Figure 12), to which the fossils from the Piesberg here described present most similarities. Also, there is one record of "Anthrapalaemon sp." from the Gzhelian of Germany. The species-group Anthrapalaemon Salter, 1861 was synonymized to Pygocephalus by Brooks (1962), so this record may refer to the latter. We could not retrieve any other information from this record, other than it appears as an occurrence on the Paleobiology Database (PaleoDB, 2021). The records show a quite interesting distribution with both Anthracaris and Pygocephalus representatives first appearing in the Lower Pennsylvanian (Bashkirian to Moscovian) of Bickershaw, Lancashire, England (Appendix 5, outcrop 25), and then in the faunas of Mazon Creek (Appendix 5, outcrop 9) and Piesberg (Moscovian) (Appendix 5, outcrop 21).

\section{Similarities Among Carboniferous Konservat- Lagerstätten: Piesberg, Mazon Creek, and Bickershaw Faunas}

The record of similar pygocephalomorphan crustaceans is an additional faunal component to fossil material from the Piesberg that is comparable to Mazon Creek and Bickershaw. The latter deposit located in Lancashire, England, is from the Westphalian A, in the regional European geological scheme, or the transition Bashkirian to Moscovian, in the IUGS chronostratigraphic chart (circa of 318.1 to $314.6 \mathrm{Ma}$, according to PaleoDB, 2021). Anderson et al. (1997) reported several fossils from Bickershaw, in which the faunal structure is typical of a near-shore, but fresh- to brackish-water habitat, as Mazon Creek (Clements et al., 2018) and Piesberg (Dunlop et al., 2008). We present below some cases of morphologically and ecologically comparable fossils among the three deposits, which give us a glimpse of a possible "faunal continuum" (Schram, 1979b) in time and space during the Bashkirian and Moscovian.

The cases presented below are only from the top of the Zweibänke coal seam in Piesberg quarry, which is temporally equal to Mazon Creek, both younger than Bickershaw.

Brauckmann and Herd (2007) described an insect wing from the Piesberg quarry, possibly a prothoracic wing of a giant "palaeopterous" representative of Pterygota that was similar to Megathentomum pustulatum Scudder, 1868, one of the two species described for large subcircular insect wings recorded at Mazon Creek. Brauckmann et al. (2015) reported two giant insect wing remains from Piesberg, which they attributed to Mazonopterum wolfforum Kukalová-Peck and
Richardson, 1983 (Paleodictyoptera), originally described for giant wing remains from Mazon Creek, with an estimated wingspan of nearly 370 mm (Kukalová-Peck and Richardson, 1983). They suggested a close palaeogeographic Euramerican connection during the Late Carboniferous. Further representatives of Insecta include a report by Haug et al. (2013) of dictyopteran nymphs with conspicuous similar external morphology to records from Mazon Creek. In Bickershaw, a wing of a protoorthopteran, a palaeodictyopteran pronotal expansion, and a single nymph wing were reported (Anderson et al., 1997).

Dunlop et al. (2008) presented a record of a scorpion, which lacked diagnostic characters that would suggest separation from other fossils identified as Eoscorpius carbonarius Meek and Worthen, 1868. Hence, this is another striking morphological similarity to a North American species. As in our case, the differences found between the two records were attributed to different types of preservation. Bickershaw has only fragments of cuticle that were attributed to scorpions, based on cuticle ornamentation (Anderson et al., 1997).

Haug et al. (2012) recognized a growth sequence composed of 10 stages of Euproops, a xiphosuridan from the Piesberg quarry. It is differentiable from the species Euproops danae from Mazon Creek, but only based on differences in the ontogenetic sequence (Haug and Rötzer, 2018; but see Lamsdell, 2020 for erecting a new genus and species for the xiphosuridan from the Piesberg quarry). In Bickershaw, there are only two specimens identified as Euproops, one of them preserved in a fish coprolite, yet there are many records of specimens identified as Bellinurus (Anderson et al., 1997). Recently, Haug and Haug (2020) suggested Belinurus (for reasons of different spelling, see Haug and Haug 2020) represents the early ontogenetic stages (stages 1-6) of Euproops; therefore, Bickershaw records of Euproops include a growth series mainly consisting of its early ontogenetic stages (Belinurus).

Fischer et al. (2019) identified that a fossil assemblage of egg capsules of chondrichthyan fishes from the Piesberg quarry includes identical species as those from Mazon Creek. Remains of vertebrates are rare in Bickershaw, fishes are represented by large scales and a single tooth from sarcopterygians.

From the eumalacostracan crustaceans, besides the record of Anthracaris and Pygocephalus, syncaridans are also present in these deposits. The Piesberg yields two yet to be described spe- 
cies of Syncarida (Leipner and Chellouche, 2019), Bickershaw has records of Palaeocaris retracta Calman, 1932, and so far the only European species Pleurocaris annulatus Calman, 1911. Mazon Creek has records of Acanthotelson stimpsonii Meek and Worthen, 1865, Palaeocaris typus Meek and Worthen, 1865, and Palaeosyncaris micra Schram, 1984 (Appendix 5).

In a "faunal continuum" context, the record of Anthracaris gracilis in Germany is yet another example of the similarities between the Upper Carboniferous faunas of North America and continental Europe.

\section{CONCLUSIONS}

The eumalacostracan crustacean from the Piesberg is a record of Anthracaris gracilis recorded previously for the Konservat-Lagerstätte Mazon Creek of North America and Bickershaw, Lancashire, England. All localities have records of strikingly similar fossils, at least in respect of external morphology. This suggests that both localities were, at least, ecologically equivalent. This strong similarity could be a product of direct exchange between the paleogeographic Euramerican lowlands formed on the north of the Alleghanian/Variscan orogenic belts.

\section{ACKNOWLEDGMENTS}

The authors would like to thank M. Sowiak (Glandorf, Germany) for his efforts in collecting material from the Piesberg quarry and willingness to provide access to specimens for scientific evaluation. We thank the GP Papenburg Company for the permission and technical support for palaeontological field work in their quarry. We gratefully appreciate the valuable comments of two reviewers, N. Clark and W. Jones, and an editorial input of Matúš Hyžný. We thank the institutions which kindly funded parts of this project: Capes/Doctoral Program (CAPES/DAAD/CNPQ, Notice n०. 152017/ Process $n^{\circ}$ 88887.161379/2017-00; PGP), Deutsche Forschungsgemeinschaft (DFG Ha 6300/3-3; JTH), and the Volkswagen Foundation (Lichtenberg professorship; JTH).

\section{REFERENCES}

Anderson, L.I., Dunlop, J.A., Horrocks, C.A., Winkelmann, H.M., and Eagar, R.M.C. 1997. Exceptionally preserved fossils from Bickershaw, Lancashire UK (Upper Carboniferous, Westphalian A [Langsettian]). Geological Journal, 32:197-210. https://doi.org/10.1002/(SICI)1099-1034(199709)32:3<197::AID-GJ739>3.0.CO;2-6

Baird, G. 1990. Mazon Creek, p. 279-282. In Briggs, D. and Crowther, P.R. (eds.), Palaeobiology: a Synthesis. Blackwell Scientific, Oxford.

Brauckmann, C. and Herd, K.J. 2007. A subcircular insect wing from the Late Carboniferous of Osnabrück, Germany. Clausthaler Geowissenschaften, 6:79-85.

Brauckmann, C., Herd, K.J., and Leipner, A. 2015. The Late Carboniferous Mazonopterum (Insecta: Palaeodictyoptera: Homoiopteridae) in Central Europe. Clausthaler Geowissenschaften, 10:1-10.

Brauckmann, C., Herd, K.J., and Leipner, A. 2021. First Eugereonidae (Insecta: Palaeodictyoptera) from the Pennsylvanian (Late Carboniferous) of the Piesberg site near Osnabrück, Germany. PalZ, online first. https://doi.org/10.1007/s12542-021-00578-3

Braun, A. 1997. Vorkommen, Untersuchungsmethoden und Bedeutung tierischer Cuticulae in kohligen Sedimentgesteinen des Devons und Karbons. Palaeontographica, Abteilung B, 245:83-156.

Brooks, H.K. 1962. The Paleozoic Eumalacostraca of North America. Bulletins of American Paleontology, 44:163-335.

Calman, W.T. 1911. III.-On Pleurocaris, a new Crustacean from the English Coal-measures. Geological Magazine, 8:156-160. https://doi.org/10.1017/s0016756800110878

Calman, W.T. 1932. Notes on Palaeocaris praecursor (H. Woodward), a fossil crustacean of the division Syncarida. Annals and Magazine of Natural History, 10:537-541.

Camacho, A.I. and Valdecasas, A.G. 2008. Global diversity of syncarids (Syncarida; Crustacea) in freshwater. Hydrobiologia, 595:257-266. https://doi.org/10.1007/s10750-007-9021-5

Clark, N.D.L. 2013. Tealliocaris: a decapod crustacean from the Carboniferous of Scotland. Palaeodiversity, 6:107-133. 
Clark, N.D.L., Gillespie, R., Morris, S.F., and Clayton, G. 2015. A new early Carboniferous crustacean from the Forest of Dean, England. Journal of Systematic Palaeontology, 14:799807. https://doi.org/10.1080/14772019.2015.1096848

Clements, T., Purnell, M., and Gabbott, S. 2018. The Mazon Creek Lagerstätte: a diverse late Paleozoic ecosystem entombed within siderite concretions. Journal of the Geological Society, 176:1-11. https://doi.org/10.1144/jgs2018-088

Cohen, K.M., Finney, S.C., Gibbard, P.L., and Fan, J.-X. 2013. The ICS International Chronostratigraphic Chart, version 2020/03. Episodes, 36:199-204. https://doi.org/10.18814/epiiugs/2013/v36i3/002

Dunlop, J.A., Brauckmann, C., and Steur, H. 2008. A Late Carboniferous fossil scorpion from the Piesberg, near Osnabrück, Germany. Fossil Record, 11:25-32. https://doi.org/10.1002/mmng.200700010

Dvořák, T., Pecharová, M., Leipner, A., Nel, A., and Prokop, J. 2021. New archaeorthopteran insects from the Pennsylvanian of Piesberg reveal unexpected mosaic of morphological traits and colouration pattern of the tegmina. Historical Biology, 33:3375-3383. https://doi.org/10.1080/08912963.2020.1867127

Fischer, J., Hartkopf-Fröder, C., Leipner, A., Schneider, J.W., Wittry, J., and Sowiak, M. 2019. A highly diverse chondrichthyan egg capsule assemblage from the Late Pennsylvanian Piesberg quarry, Northwest Germany. Kölner Forum für Geologie und Paläontologie, Conference Proceedings of the 19th International Congress on the Carboniferous and Permian, 23:105-106.

Fong, C.C.K. 1972. Bellocaris, a new Mississippian crustacean from Newfoundland. Journal of Paleontology, 46:594-597. https://www.jstor.org/stable/1303007

Gueriau, P., Charbonnier, S., and Clément, G. 2014. First decapod crustaceans in a late Devonian continental ecosystem. Palaeontology, 57:1203-1213. https://doi.org/10.1111/pala.12111

Haug, C., Mayer, G., Kutschera, V., Waloszek, D., Maas, A., and Haug, J.T. 2011. Imaging and documenting gammarideans. International Journal of Zoology, 2011:380829. https://doi.org/10.1155/2011/380829

Haug, C., Van Roy, P., Leipner, A., Funch, P., Rudkin, D.M., Schöllmann, L., and Haug, J.T. 2012. A holomorph approach to xiphosuran evolution-a case study on the ontogeny of Euproops. Development Genes and Evolution, 222:253-268. https://doi.org/10.1007/s00427-012-0407-7

Haug, C. and Rötzer, M.A.I.N. 2018. The ontogeny of the 300 million year old xiphosuran Euproops danae (Euchelicerata) and implications for resolving the Euproops species complex. Development Genes and Evolution, 228:63-74. https://doi.org/10.1007/s00427-018-0604-0

Haug, C. and Haug, J.T. 2020. Untangling the Gordian knot-further resolving the super-species complex of 300-million-year-old xiphosurids by reconstructing their ontogeny. Development Genes and Evolution, 230:13-26. https://doi.org/10.1007/s00427-020-00648-7

Haug, J.T., Leipner, A., Wappler, T., and Haug, C. 2013. Paleozoic insect nymphs: new finds from the Piesberg quarry (Upper Carboniferous, Germany). Bulletin of Geosciences, 88:779791. https://doi.org/10.3140/bull.geosci.1401

Hörnig, M.K., Haug, C., Herd, K.J., and Haug, J.T. 2014. New insights into dictyopteran early development: smallest Palaeozoic roachoid nymph found so far. Palaeodiversity, 7:159-165.

Huxley, T.H. 1857. Description of a new crustacean (Pygocephalus cooperi, Huxley) from the Coal Measures. Quarterly Journal of Geological Society, 13:363-369. https://doi.org/10.1144/gsl.jgs.1857.013.01-02.45

Jones, W.T., Feldmann, R.M., Schram, F.R., Schweitzer, C.E., and Maguire, E.P. 2016. The proof is in the pouch: Tealliocaris is a peracarid. Palaeodiversity, 9:75-88. https://doi.org/10.18476/pale.v9.a5

Jones, W.T., Feldmann, R.M., Schweitzer, C.E., Schram, F.R., Behr, R.-A., and Hand, K.L. 2018. The first Paleozoic stenopodidean from the Huntley Mountain Formation (DevonianCarboniferous), north-central Pennsylvania. Journal of Paleontology, 88:1251-1256. https://doi.org/10.1666/13-059

Johnson, R.G. and Richardson, E.S., Jr. 1966. A remarkable Pennsylvanian fauna from the Mazon Creek area, Illinois. Journal of Geology, 74:626-631. https://doi.org/10.1086/627194 
Kukalová-Peck, J. and Richardson, E.S. Jr. 1983. New Homoiopteridae (Insecta: Paleodictyoptera) with wing articulation from Upper Carboniferous strata of Mazon Creek, Illinois. Canadian Journal of Zoology, 61:1670-1687. https://doi.org/10.1139/z83-218

Lamsdell, J.C. 2020. The phylogeny and systematics of Xiphosura. PeerJ, 8:e10431. https://doi.org/10.7717/peerj.10431

Leipner, A. and Chellouche, P. 2019. A newly discovered lake deposit of Pennsylvanian age (upper Moscovian, Westphalian D) from the Piesberg quarry, Osnabrück, Northwestern Germany. Proceedings of the 19th International Congress on the Carboniferous and Permian, Cologne, 24:197-198.

Meek, F.B. and Worthen, A.H. 1865. Notice on some new types of organic remains from the Coal Measures of Illinois. Proceedings of the Academy of Natural Sciences of Philadelphia, 17:4148. https://www.jstor.org/stable/4623982

Meek, F.B. and Worthen, A.H. 1868. Preliminary notice of a scorpion, a Eurypterus? and other fossils from the Coal Measures of Illinois and lowa. American Journal of Science and Arts, 45:19-28.

Nel, A., Roques, P., Nel, P., Prokin, A.A., Bourgoin, T., Prokop, J., Szwedo, J., Azar, D., DesutterGrandcolas, L., Wappler, T., Garrouste, R., Coty, T., Huang, D., Engel, M.S., and Kirejtshuk, A.G. 2013. The earliest known holometabolous insects. Nature, 503:257-261. https://doi.org/10.1038/nature12629

PaleoDB. 2021. Carboniferous Eumalacostraca occurrence data, 42 records downloaded 12 February 2021. Paleobiology Database. https://paleobiodb.org/\#/

Pazinato, P.G., Haug, C., Leipner, A., and Haug, J.T. 2018. A new glimpse into the early diversification of peracarid crustaceans - An exceptionally preserved pygocephalomorph from the Upper Carboniferous of Germany. Conference Proceedings of GeoBonn, Bonn, p. 250.

Peach, B. 1882. XXI.-Further Researches among the Crustacea and Arachnida of the Carboniferous Rocks of the Scottish Border. Transactions of the Royal Society of Edinburgh, 30:511-529. https://doi.org/10.1017/S0080456800026569

Peach, B. 1908. I.-Monograph on the Higher Crustacea of the Carboniferous Rocks of Scotland. Memoirs of the Geological Survey of Great Britain: Palaeontology. 4:1-82. https://doi.org/10.5962/bhl.title.10510

Prestwich, J. 1840. On the geology of Coalbrook Dale. Transactions of the Geological Society of London, 5:413-495. https://doi.org/10.1144/transgslb.5.3.413

Richter, S. and Scholtz, G. 2001. Phylogenetic analysis of the Malacostraca (Crustacea). Journal of Zoological Systematics and Evolutionary Research, 39:113-136. https://doi.org/10.1046/j.1439-0469.2001.00164.x

Salter, J.W. 1861. On some of the Higher Crustacea from the British Coal-Measures. Quarterly Journal of the Geological Society, 17:528-533. https://doi.org/10.1144/GSL.JGS.1861.017.01-02.44

Schädel, M., Pazinato, P.G., van der Wal, S., and Haug, J.T. 2019. A fossil tanaidacean crustacean from the Middle Jurassic of southern Germany. Palaeodiversity, 12: 13-30. https://doi.org/10.18476/pale.v12.a2

Schram, F.R. 1974. The Mazon Creek Caridoid Crustacea. Fieldiana: Geology, 30:9-65. https://doi.org/10.5962/bhl.title.3154

Schram, F.R. 1979a. British Carboniferous Malacostraca. Fieldiana: Geology, 40:11-29. https://doi.org/10.5962/bhl.title.3360

Schram, F.R. 1979b. The Mazon Creek biotas in the context of a Carboniferous faunal continuum, p. 159-190. In Nitecki, M.H. (ed.), Mazon Creek Fossils. Academic Press, New York. https://doi.org/10.1016/B978-0-12-519650-5.50015-1

Schram, F.R. 1981. Late Palaeozoic crustacean communities. Journal of Paleontology, 55:126137. http://www.jstor.org/stable/1304334

Schram, F.R. 1984. Fossil Syncarida. Transaction of the San Diego Society of Natural History, 20:189-246. https://doi.org/10.5962/bhl.part.29006

Schram, F.R. 1986. Crustacea. Oxford University Press, New York.

Schram, F.R., Ahyong, S.T., Patek, S.N., Green, P.A., Rosario, M.V., Bok, M.J., Cronin, T.W., Mead Vetter, K.S., Caldwell, R.L., Scholtz, G., Feller, K.D., and Abello, P. 2013. Subclass Hoplocarida Calman, 1904: Order Stomatopoda (Latreille, 1817). In von Vaupel Klein, J.C., Charmantier-Daures, M., and Schram, F.R. (eds.), Treatise on Zoology - Anatomy, Taxonomy, Biology. The Crustacea. Brill, Leiden, 179-355. 
Schultka, S. 2000. Zur Palökologie der Euproopiden im Nordwestdeutschen Oberkarbon. Mitteilungen aus dem Museum für Naturkunde in Berlin. Geowissenschaftliche Reihe, 3:8798. https://doi.org/10.5194/fr-3-87-2000

Scudder, S.H. 1868. Entomological Notes. Proceedings of the Boston Society of Natural History, 6:7-9. https://doi.org/10.5962/bhl.title.16203

Taylor, R.S., Yan-Bin, S., and Schram, F.R. 1998. New pygocephalomorph crustaceans from the Permian of China and their phylogenetic relationships. Palaeontology, 41:815-834.

Walossek, D. 1999. On the Cambrian diversity of Crustacea, p. 3-27. In Schram, F.R. and von Vaupel Klein, J.C. (eds.), Crustaceans and the Biodiversity Crisis. Brill, Leiden.

Whitfield, R.P. 1880. Notice of a new form of fossil crustaceans from the Upper Devonian rocks of Ohio, with descriptions of new genera and species. American Journal of Science, 19:3342. https://doi.org/10.2475/ajs.s3-19.109.33

WoRMS, Editorial Board. 2021. Carboniferous Eumalacostraca occurrence data, 764 records downloaded 10 February 2021. World Register of Marine Species. https://www.marinespecies.org. https://doi.org/10.14284/170

Wrede, V., Drozdzewski, G., Juch, D., and Leipner, A. 2019. Field Trip A2: The Pennsylvanian of the Ruhr Basin and Osnabrück region, western Germany - facies, stratigraphy and tectonics of a paralic foreland basin of the Variscides, p. 43-80. In Herbig, H.G., Aretz, M., Amler, M.R.W., and Hartenfels, S. (eds.), Field guides of the 19th International Congress on the Carboniferous and Permian, Cologne, Germany

Zessin, W. 2008. Einige Aspekte zur Biologie paläozoischer Libellen (Odonatoptera). Entomologia Generalis, 31:261-278. https://doi.org/10.1127/entom.gen/31/2008/261

Zessin, W., Brauckmann, C., and Gröning, E. 2021a. A new insect (probably basal Odonatoptera) from the Pennsylvanian (Late Carboniferous) of the Piesberg FossilLagerstätte, Osnabrück, Germany. Palaeontomology, 4:532-536. https://doi.org/10.11646/ palaeoentomology.4.6.2

Zessin, W., Brauckmann, C., and Leipner, A. 2021b. Sowiakala perprocera n. g. n. sp. (Sowiakalidae n. fam.) - eine interessante Libelle (Insecta: Odonatoptera: Protozygoptera) aus dem unteren Westfalium D (Pennsylvanium, Oberkarbon) vom Piesberg bei Osnabrück. Clausthaler Geowissenschaften, 11:23-30. 


\section{APPENDICES}

\section{APPENDIX 1.}

Measurements of the specimens of Anthracaris gracilis (Meek and Worthen, 1865) from Piesberg and of $A$. gracilis taken from Brooks (1962). (A) Raw values, in millimetres. (B) Normalised values. Abbreviations: $\mathrm{NA}=$ not available. (All appendices available online as zipped file at https://palaeo-electronica.org/content/2022/3506-eumalacostracan-from-piesberg.)

\section{APPENDIX 2.}

Table of eumalacostracan and phyllocaridan records of the Carboniferous of North America, the UK and continental Europe. (All appendices available online as zipped file at https://palaeo-electronica.org/content/2022/3506-eumalacostracan-from-piesberg.)

\section{APPENDIX 3.}

List of references used for frequencies and geographical distribution plots. (All appendices available online as zipped file at https://palaeo-electronica.org/content/2022/3506-eumalacostracanfrom-piesberg.)

\section{APPENDIX 4.}

Geographic distribution of outcrops which present records of Eumalacostraca, and its sistergroup Phyllocarida, during the Mississippian of North America (A), continental Europe (B) and north of the UK (C). (All appendices available online as zipped file at https://palaeo-electronica.org/content/2022/3506-eumalacostracan-from-piesberg.)

\section{APPENDIX 5.}

Geographic distribution of outcrops which present records of Eumalacostraca, and its sistergroup Phyllocarida, during the Pennsylvanian of North America $(A)$, continental Europe and the UK (B). (All appendices available online as zipped file at https://palaeo-electronica.org/content/ 2022/3506-eumalacostracan-from-piesberg.)

\section{APPENDIX 6.}

Time span of the species of Eumalacostraca, and its sister-group Phyllocarida, during the Carboniferous of North America, the UK and continental Europe. Abbreviation: Ks, Kasimovian. (All appendices available online as zipped file at https://palaeo-electronica.org/content/2022/3506eumalacostracan-from-piesberg.) 